\title{
Papillary cystadenoma of right testis: Case report and literature review
}

\author{
Otobo O. Fidelis ${ }^{* 1}$, Ikpi Edet ${ }^{1}$, Enakirerhi Glen ${ }^{1}$, Isiwele M. Edoise ${ }^{1}$, Omotosho Ayodele ${ }^{2}$, Essiet Akanimo ${ }^{1}$, Paul D \\ Ekwere $^{1}$, Edet O Nkposong ${ }^{1}$ \\ ${ }^{1}$ Division of Urology, Department of Surgery, University of Calabar Teaching Hospital, Calabar, Nigeria \\ ${ }^{2}$ Division of Urology, Department of Patholog, University of Calabar Teaching Hospital, Calabar, Nigeria
}

Received: December 28, 2016

Accepted: March 16, 2017

Online Published: April 10, 2017

DOI: $10.5430 /$ crcp.v4n2p8

URL: https://doi.org/10.5430/crcp.v4n2p8

\begin{abstract}
Testicular cystadenoma is ranked the second commonest benign neoplasm. Other benign epididymal neoplasms include adenomatoid tumor (most common), leiomyoma, serous (nonpapillary) cystadenoma, cavernous hemangioma, and melanotic neuroectodermal tumor. Adenocarcinoma, mesothelioma, and metastatic renal cell carcinoma are malignant tumors that can affect the epididymis. A 24-year-old male undergraduate with a 3-month history of mildly tender right testicular swelling histologically diagnosed as papillary cystadenoma is presented. This case is presented from our locality as the first of its' kind; and because it can be a possible manifestation of other diseases like von Hippel- Lindau (VHL) disease.
\end{abstract}

Key Words: Cystadenoma, Testes

\section{INTRODUCTION}

Tumours of the epididymis comprise about $5 \%$ of intrascrotal tumours. Papillary cystadenoma (PCE) of the testis is second only to adenomatoid tumour in this category. ${ }^{[1-4]}$ It is an epithelial tumour believed to develop in the efferent ductules. ${ }^{[2-4]}$ Sherrick was the first to describe it in a 21-year-old in $1956 .{ }^{[5]}$ The history however dates as far back as 1921 , when Brandt found an "epididymal cyst" in an autopsy of a patient for which von Hippel had previously reported retinal lesions. ${ }^{[6]}$ Papillary cystadenoma can occur sporadically or as a manifestation of VHL disease (about $2 / 3$ have VHL disease). ${ }^{[7-9]}$ Tsuda et al. have described a familial pattern. ${ }^{[10]}$ PCE shows a strong histologic resemblance to metastatic renal cell carcinoma. ${ }^{[7-9]}$ Macroscopic lesions arise in 50\% of VHL male patients and it is believed that microscopic lesions will be present in all male VHL patents. ${ }^{[9]}$ The walls are usually studded with nodules of epithelial cells arranged in a globular or papillary configuration. Treatment is surgery with good prognosis. A few cases of late transformation into cystadenocarcinoma have been reported. ${ }^{[11]}$

\section{CASE REPORT}

A 24-year-old male with a 3-month history of mildly tender right testicular swelling. No history of trauma, abdominal pains or swelling. No history of impaired vision, breathing, hearing or gait disorders suggestive of VHL disease.

Examination revealed a young man in apparent general good health with vital signs within normal range. Both testicles were about $15 \mathrm{ml}$ volume and the left epididymis as well as both vasa deferentia were essentially normal. There was a $1 \mathrm{~cm}$ firm oval nodule over the caput of the right epi-

${ }^{*}$ Correspondence: Otobo O. Fidelis; Email: otobof@yahoo.com; Address: Division of Urology, Department of Surgery, University of Calabar Teaching Hospital, Calabar, Nigeria. 
didymis. There were bilateral varicoceles but no regional lymphadenopathy.

Testicular ultrasound scans revealed slight probe tenderness and a bulky right epididymis measuring $13.7 \mathrm{~mm} \times$ $15.6 \mathrm{~mm}$ with a nodular hypoechoic area measuring $11.9 \mathrm{~mm} \times 13.9 \mathrm{~mm}$ in size. It also showed marginal increase in blood flow on colour doppler.

Blood picture revealed packed cell volume of $42 \%$, lymphocytes of $44 \%$ and serum prolactin of $13.4 \mathrm{ng} / \mathrm{ml}$ (3.6-16.3). Seminal fluid analysis was essentially normal. Urinalysis revealed no abnormal findings.

He underwent excision biopsy and histology showed tissues composed of dilated ducts with cystic spaces and papillary projections lined by a single layer of columnar cells, having vacuolated cytoplasm. The stroma was densely fibrous with focal areas of hyalinization and patchy chronic inflammation (see Figures $1 \& 2$ ). No evidence of malignancy was seen. The patient was requested to obtain abdomino-pelvic ultrasound and brain CT-scans for follow up.

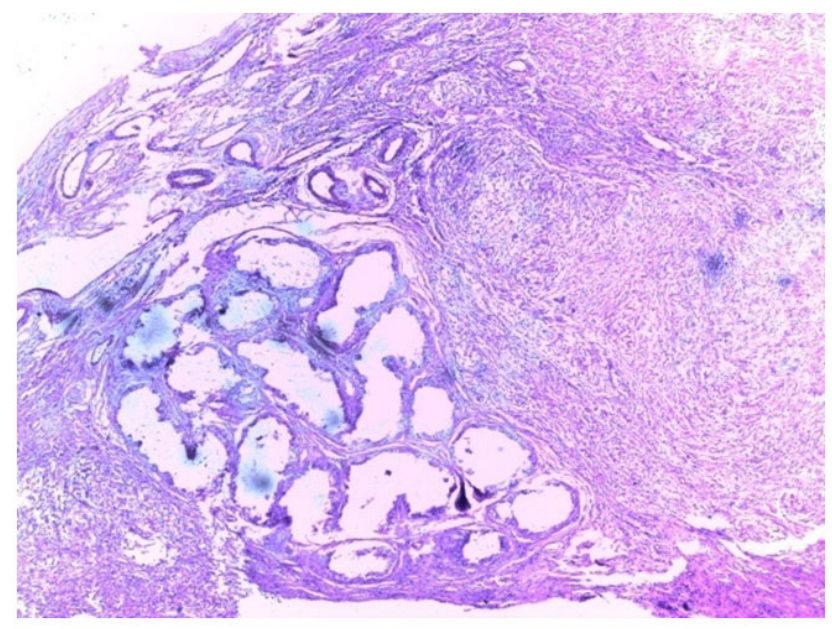

Figure 1. Papillary cystadenoma of the testis $(H \& E \times 40)$

\section{DISCUSSION}

Papillary cystadenoma is common in post-pubertal males 16-65 years (mean age 36). ${ }^{[5,7]}$ Unilateral cases are commoner and bilateral cases occur especially in patients that have been diagnosed with VHL disease before. ${ }^{[12]}$ In a study of 8 patients with unilateral PCE, none was found to develop VHL disease at a follow-up period of between 18 months and 15 years. ${ }^{[13]}$ In recent studies however, PCE or its precursors have been found in all the epididymii of patients having VHL disease that were examined. ${ }^{[14,15]}$

Two-thirds of patients with PCE have an increased probability of developing benign cysts of the kidneys and pancreas, as well as tumours of the CNS, adrenals, and reproductive adnexial organs. ${ }^{[9]}$ This risk is higher in bilateral cases. ${ }^{[11]}$

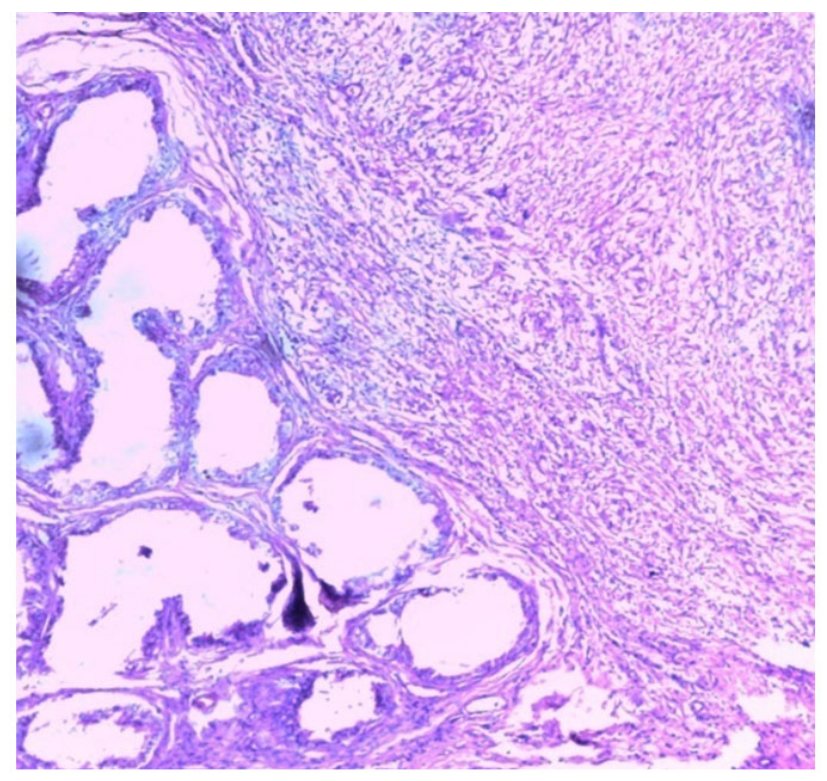

Figure 2. Papillary cystadenoma of the testis $(H \& E \times 100)$

PCE is most commonly located at the head of the epididymis $^{[7]}$ (as in our own case), although Gaffey et al. have described a solitary case in the broad ligament associated with VHL disease. ${ }^{[16]}$ It often presents as a painless, slowly growing scrotal swelling. ${ }^{[12]}$ Typically PCE is less than $5 \mathrm{~cm}$ in size. ${ }^{[8,17]}$

Histologic characteristics are cysts filled with prominent intracystic papillary projections. ${ }^{[12]}$ These papillae contain fibrovascular cores lined by single layer of bland cuboidal or columnar epithelium. ${ }^{[12]}$ Cytoplasmic clearing is an obvious finding almost in all reported cases. ${ }^{[12]}$

Metastatic renal cell carcinoma, a strong differential diagnosis of PCE, may co-exist with it in patients with VHL ${ }^{[7]}$ possibly due to the mesosnephric tissue origin of both renal tubules and the efferent ductules of the epididymis. The early recognition and management of this tumour may help prevent possible late malignant transformation and also pave way for early identification of more pathologic entities like VHL and its associated lesions. 


\section{REFERENCES}

[1] Juan G, Jesse KM. The Pathology of von Hippel-Lindau Disease. Pathol. Case Rev. 2014.

[2] Nausheen Y, Aamir A, Zubair A, et al. Clear cell papillary cystadenoma of epididymis, a mimic of metastatic renal cell carcinoma. Dept. Pathol. Microbiol. Aga Khan Univ. Karachi.

[3] Kuhn MT, Maclennan GT. Benign neoplasms of the epididymis. J. Urol. 2005; 174: 723-726. PMid: 16006963. https://doi.org/ 10.1097/01.ju.0000170979.21638.e4

[4] Aydin H, Young RH, Ronnett BM, et al. Clear cell papillary cystadenoma of the epididymis and mesosalpix; immunohistochemical differentiation from metastatic clear cell renal cell carcinoma. Am. J. Pathol. 2005; 29: 5203.

[5] Sherrick JC. Papillary cystadenoma of the epididymis. Cancer. 1956; 9: 403-447. https://doi.org/10.1002/1097-0142(19 5603/04) 9:2<403: : AID-CNCR2820090226>3.0.CO;2-Q

[6] Melmon KL, Rosen SW. Lindau's disease: review of the literature and study of a large kindred. Am. J. Med. 1964; 36: 595-617. https://doi.org/10.1016/0002-9343(64)90107-X

[7] Kragel PJ, Pestamer J, Travis WD, et al. Papillary cystadenoma of the epididymis; three cases with lectin immunohistochemistry. Arch Pathol. Lab Med. 1990; 114: 672-675. PMid: 1694653.

[8] Gilcrease MZ, Schmidt L, Zbar B, et al. Somatic von Hippel-Lindau mutation in clear cell papillary cystadenoma of the epididymis. Hum. Pathol. 1995; 26: 1341-1346. https://doi.org/10.1016/0046 -8177 (95) 90299-6

[9] Russel RL, Gladys MG, McClellan W, et al. von Hppel-Lindau disease. The Lancet. 2003; 361.
[10] Tsuda H, Fakushima S, Takahashi M, et al. Familial bilateral papillary cystadenoma of the epididymis. Cancer. 1976; 37: 1831-1839. https : //doi.org/10.1002/1097-0142(197604)3 $7: 4<1831$ : : AID-CNCR2820370430>3.0.CO;2-V

[11] de Souza AJ, Bambirra EA, Bicalho OJ, et al. Bilateral papillary cystadenoma of the epididymis as a component of von Hippel-Lindau's syndrome; Report of a case presenting as infertility. J. Urol. 1985; 133: 288-289. PMid: 3968752.

[12] Karen JO, Sanjay M. Papillary Cystadenoma of the Epididymis. Arch Pathol Lab Med. 2010; 134: 630-633.

[13] Price EB Jr. Papillary cystadenoma of the epididymis: a clinicopathologic analysis of 20 cases. Arch Patho. 1971; 91: 456-470.

[14] Mehta GU, Shively SB, Duong H, et al. Progression of epididymal maldevelopment into hamartoma-like neoplasia in VHL disease. Neoplasia. 2008; 10: 1146-1153. PMid: 18813354. https : //doi.org/10.1593/neo.08476

[15] Glasker S, Tran MG, Shively SB, et al. Epididymal cystadenomas and epithelial tumourlets: effects of VHL deficiency on the human epididymis. J. Pathol. 2006; 210: 32-41. PMid: 16841375. https://doi.org/10.1002/path. 2029

[16] Gaffey MJ, Mills SE, Boyd JC. Aggressive papillary tumour of middle ear/temporal bone and adnexial papillary cystadenoma. Manifestation of VHL disease. Am. J. Surg. Pathol. 1994; 18: 1254-1256. PMid: 7977949. https ://doi.org/10.1097/00000478-19941 2000-00009

[17] Uppuluri S, Bhatt S, Tang P, et al. Clear cell papillary cystadenoma with sonographic and histopathologic correlation. J Ultrasound Med. 2006; 25: 1451-1453. PMid: 17060433. https://doi.org/10.7 863/jum.2006.25.11.1451 